\title{
KATARZYNA SKRZYPIŃSKA
}

\section{CODZIENNE I DUCHOWE ŚCIEŻKI KOBIET ŚRODKOWEGO WSCHODU - NEPALKI, TYBETANKI I BHUTANKI ${ }^{1}$}

\begin{abstract}
Skrzypińska Katarzyna, Codzienne i duchowe ścieżki kobiet Środkowego Wschodu - Nepalki, Tybetanki i Bhutanki [Everyday and spiritual paths of the women in Middle East - Nepalese, Tibetan and Bhutanese Women] edited by M. Krajewski - „Człowiek i Społeczeństwo”, vol. XXXIII, Poznań 2012, pp. 153-176. Adam Mickiewicz University Press. ISBN 978-83-232-2484-6. ISSN 0239-3271.
\end{abstract}

Diversity, which is characteristic feature of Middle Asia, attracts attention of tourists, adventures' seekers, scientists and others. It is so fascinating to compare the three countries - such dissimilar as Nepal, Tibet and Bhutan. The article presents everyday and spiritual life of the people and especially women from these countries, on the religious - Hindu and Buddhist - background.

Katarzyna Skrzypińska, Uniwersytet Gdański, Instytut Psychologii, ul. Bażyńskiego 4, 80-952 Gdańsk, Poland.

Azja poraża kolorytem. Różnorodność stanowiąca jej charakterystyczną cechę jak magnes przyciąga badaczy, turystów, poszukiwaczy przygód czy wreszcie głodnych duchowej strawy. Zastanawia fakt, że na jednym kontynencie leżą kraje tak odmienne względem siebie z powodu różnic w mentalności, kulturze i wierzeniach. Na przykład, na obszarze trzech krajów Środkowej Azji - Nepalu, Tybetu i Bhutanu - spotykamy religie mające korzenie zarówno hinduistyczne, jak i buddyjskie, co ma znaczny wpływ na pojawiające się różnice w życiu codziennym. W tło wyznaniowe dodatkowo wpisuje się odmienna rola kobiety i mężczyzny we wspomnianych krajach. Mamy bowiem do czynienia z kolektywistyczną kulturą. Znacznie odróżnia

1 Niniejszy artykuł jest owocem wyprawy autorki do wspomnianych krajów. Ciekawostki oraz liczne terminy krajoznawczo-kulturowe zostały częściowo zaczerpnięte z wykładów Kajetana Gosławskiego, znanego podróżnika i dokumentalisty, badacza ginących ludów, któremu dziękuję za cenne i nietuzinkowe komentarze w czasie naszej wspólnej wyprawy. Dziękuję bardzo Nataszy Kosakowskiej za intencję naprowadzenia mnie na drogę wątków genderowych. 
to role płci od tych przyjętych w krajach europejskich. Refleksje zawarte $\mathrm{w}$ niniejszym artykule mają na celu stworzenie syntetycznego szkicu opisującego specyfikę życia kobiet Nepalu, Tybetu i Bhutanu, natomiast nie oferują pełnej, wyczerpującej charakterystyki miejsc, w których żyją². To zastrzeżenie pozwala na wyłonienie jednego, specyficznego wątku, którego podjęła się autorka - wątku genderowego.

\section{DLACZEGO NEPAL-TYBET-BHUTAN?}

Dlaczego akurat miejsca wymienione w podtytule stanowią główny punkt odniesienia?

Po pierwsze wymienione kraje stanowią niezwykły kontrast pomimo swojego sąsiedztwa i azjatyckiej lokalizacji. Dotyczy ona zarówno warunków geograficzno-klimatyczno-przyrodniczych, jak i kulturowych. Szczególnie ciekawym aspektem są religie: $\mathrm{w}$ Nepalu panują hinduistyczne i jednocześnie buddyjskie, w Tybecie i w Bhutanie zaś dominuje buddyzm tantryczny (tzw. lamaizm). Dlatego też im poświęcony zostanie osobny rozdział niniejszego artykułu. Jednocześnie na wszystkich tych obszarach widoczne są wpływy religii bon i animizmu - dawnych wierzeń ludów zamieszkujących ten piękny, choć mało przyjazny teren. Jak pisze Grzymała-Moszczyńska (2004, s. 11): „Konieczne jest dostrzeżenie, jak treści doktryny religijnej i wydarzenia historyczne kształtowały w przeszłości i kształtują obecnie sposoby zachowania człowieka". Nie można zatem tych czynników rozpatrywać jako zatomizowanych.

Po drugie - ich bliskość umożliwia podróż brzemienną $\mathrm{w}$ natychmiastowe porównania, „na świeżo”. Bowiem zaledwie godzina lotu samolotem pozwala na przemieszczanie się pomiędzy nimi. Daje to sposobność zestawienia pierwszych wrażeń, bez obciążenia czynnikiem upływu czasu.

Po trzecie, wspólnym mianownikiem wszystkich trzech krajów są Himalaje - majestatyczne, wymagające, wręcz surowe, od wieków determinujące ludzką egzystencję i przetrwanie (Himalaya - Dom Śniegów). W tak surowych warunkach, na północy Nepalu żyją sławni Szerpowie, którym nieobca jest choroba wysokościowa i światowy pęd do bicia rekordów w zdobywaniu Mount Everestu. Tybet z częścią Himalajów i Wyżyną Tybetańską, poza bajecznym, nierealnym wręcz krajobrazem w dolinie Brahmaputry, wita surowym klimatem - suchym i ubogim w tlen oraz roślinność, co zobowiązuje do pokory wobec sił natury. Znacznie łagodniejsze warun-

2 Zachęcam do uzupełnienia wiedzy na temat Nepalu, Tybetu i Bhutanu, czytając istniejące przewodniki oraz publikacje naukowe (np. vide: bibliografia niniejszego artykułu). 
ki, choć również górzyste, oferuje Królestwo Bhutanu, gdzie wprawdzie większość gór porasta bujna roślinność, jednak znaczna wysokość także jest odczuwalna.

Po czwarte, pomimo bliskiego sąsiedztwa, historia nakreśliła zupełnie różne scenariusze rozwoju i sytuacji społeczno-politycznej trzech analizowanych krajów. Najliczniej odwiedzanym z nich jest Nepal (Federalna Demokratyczna Republika Nepalu), który u podnóża Himalajów stanowi ważny punkt komunikacyjny - w Katmandu funkcjonują liczne połączenia lotnicze do innych najbliższych stolic i miast, m.in. do Lhasy (stolicy Tybetu) i Paro (jedynego międzynarodowego lotniska Bhutanu). Tutaj żyje najliczniejsze, wielonarodowe $\mathrm{w}$ porównaniu do państw ościennych społeczeństwo (Nepalczycy, Biharczycy, Tharowie, Tamangowie, Newarowie i inni), bo złożone $\mathrm{z}$ ponad 28,6 miliona osób (203 osoby/ $\left.\mathrm{km}^{2}\right)$. Warunki naturalne, zwłaszcza te wysokogórskie (cztery strefy klimatyczne), związane $\mathrm{z}$ aktywnością sejsmiczną oraz nizinne związane $\mathrm{z}$ rozprzestrzenianiem się malarii, przyczyniły się do stosunkowo długiej izolacji i słabej urbanizacji kraju - braku linii kolejowej, słabej jakości dróg, braku systemu kanalizacji w miastach itp. Dopiero przybyli na te ziemie w 1768 r. Gurkhowie przynieśli ze sobą pojęcie państwa i dokonali zjednoczenia Nepalu. Późniejsze burzliwe losy wieloletniej monarchii, zaangażowanej w konflikty z Chinami i Indiami nadają rys współczesnemu życiu w Dolinie Katmandu i obszarach przyległych (Ross, Le Bas \& Bell 2009).

Najbardziej tajemniczym, a zarazem intrygującym krajem z opisywanych tutaj wydaje się Tybet, który po raz pierwszy mocniej zaznaczył swoje istnienie na kartach historii poprzez podbój północnych Chin w IV wieku naszej ery (Kalmus 2009). Dzieje Dachu Świata przeplatają się z licznymi mitami i legendami opisującymi poszczególnych przedbuddyjskich królów z czasów szerzenia się religii bon (Néel 2011/1929). Jednak przełomowe znaczenie miało pojawienie się w Tybecie Guru Rinpocze, jogina i mistyka, któremu przypisywano nadludzkie moce. To on przyczynił się do osłabienia pierwotnej religii bon i rozpropagował nauki Buddy oraz wzniósł pierwszy na tych ziemiach klasztor w Samje. Wkrótce wielcy mistrzowie, w tym Tsongkhapa, zainicjowali powstanie wielu uniwersytetów klasztornych Tybetu Środkowego (m.in. Wielka Trójka: Sera, Drepung i Ganden). Od XVI wieku państwem władali kolejni Dalaj Lamowie. W 1912 roku kraj został ustanowiony monarchią teokratyczną. Niestety radość z otwarcia się na świat przysłoniła w 1950 roku inwazja Chin argumentowana "potrzebą ochrony granic i przeprowadzenia demokratycznych reform" (Kalmus 2009). Aktualnie Dach Świata funkcjonuje jako Tybetański Region Autonomiczny Chin. Z kraju, wraz z Dalaj Lamą XIV uciekło do tej pory ponad 100 tys. mieszkańców - stąd brak ścisłych statystyk dotyczących aktualnego 
zaludnienia (szacuje się, że tereny Tybetu zamieszkuje ok. $7 \mathrm{mln}$. rdzennych mieszkańców). Te dramatyczne wydarzenia doprowadziły do migracji ludu przez Himalaje do Nepalu, a także do Indii, gdzie rozpoczęto tworzenie tybetańskich szkół dla dzieci i młodzieży. Niezwykły heroizm kilkuletnich dzieci oraz ich matek pogodzonych z wieloletnia rozłąką niejednokrotnie ukazywały telewizyjne filmy dokumentalne.

Znacznie mniej burzliwą historię swoich korzeni przedstawiają Bhutańczycy, południowi sąsiedzi Tybetańczyków. Tak naprawdę bramy ich państwa dla podróżników, turystów i badaczy zostały otwarte dopiero w latach 70. ubiegłego wieku. Co ciekawe, do lat 60 . kraj ten pozostawał we względnej izolacji społecznej w stosunku do innych z powodu braku połączeń lotniczych i odpowiedniej infrastruktury, co miało znaczący wpływ na specyfikę życia rodzin bhutańskich. Od niedawna istniejące tam drogi asfaltowe umożliwiają $\mathrm{w}$ miarę sprawne przemieszczanie się. Do początku XVII wie$\mathrm{ku}$ nie było też jednolitego państwa Bhutanu, podobnie jak na obszarze Nepalu. Aktualnie Bhutan stanowi monarchię konstytucyjną, zamieszkaną przez nieco ponad 700 tys. mieszkańców (16 osób/ km² - Pommaret 2008), na terytorium mniejszym niż Szwajcaria (gdzie żyje prawie $8 \mathrm{mln}$ ludzi). Ciekawym, lecz niepokojącym zjawiskiem jest to, że ludzie, którzy przez wieki żyli w praktycznie hermetycznej izolacji cywilizacyjnej dzisiaj dostają telewizory plazmowe $\mathrm{z}$ dostępem do telewizji satelitarnej.

Powyższy opis sygnalizuje jak różnorodne warunki terytorialnopolityczno-społeczne ukształtowały kulturę na tych ziemiach. A jak uważa Triandis (2007) kultura jest wynikiem interakcji człowieka ze środowiskiem, stanowi zbiór wspólnych praktyk i znaczeń, łączących jej uczestników. Składa się na nią ogół duchowego i materialnego dorobku, który niezaprzeczalnie reguluje relacje pomiędzy obiema płciami. W takich warunkach kształtuje się tożsamość rodzajowa (Bem 2000), inaczej płeć kulturowa, czyli zespół atrybutów, postaw, ról społecznych i zachowań przypisanych mężczyźnie lub kobiecie przez szeroko rozumianą kulturę. Zgodnie z Deaux i Lewisem $(1983,1984)$ męska i kobieca tożsamość stanowi komponenty stereotypów rodzaju, nabywanych w procesie socjalizacji. Stereotyp kobiecości niesie ze sobą wiedzę, że kobieta jest źródłem wsparcia emocjonalnego dla innych, zarządza domem, opiekuje się dziećmi i odpowiada za funkcjonalne urządzenie domu. Z kolei stereotyp męskości utrzymuje, że mężczyzna stanowi głowę domu, finansuje utrzymanie rodziny i odpowiada za domowe naprawy. Przy czym badania pokazują, że tożsamość rodzajowa kobiet jest bardziej spójna i skrystalizowana niż u mężczyzn (Boski 2005). Empiryczna weryfikacja dokonana przez Kosakowską (2004) pokazała, że nawet u sześciolatków, a także u nastolatków i osób po trzydziestym roku 
życia występuje zgodność co do tego, jakie zadania i czynności są typowo kobiece, a jakie męskie.

Perspektywa przyjęta w niniejszym artykule bazuje na teorii Hofstede (2000), która zakłada istnienie kilku istotnych wymiarów występujących w analizie zjawisk międzykulturowych. Są to: dystans władzy, unikanie niepewności, indywidualizm-kolektywizm i męskość-kobiecość (por. Hofstede i Hofstede 2007). Ich wnikliwą analizę na gruncie wielokulturowych organizacji przeprowadziły Chybicka, Kosakowska-Berezecka i Petrus (2010). Wymiarem szczególnie interesującym ze względu na podjęty w niniejszym artykule temat - jest ten ostatni, rodzajowy.

\section{ŻYCIE CODZIENNE I JEGO JAKOŚĆ}

Według Hofstede (2000) w każdej kulturze role kobiece to dbanie o sferę uczuć i zachowanie harmonii, troska o jakość życia, a role męskie to twardość, asertywność i „przebojowość". Jednak w kulturach kobiecych zachowania obu płci są podobne i zbliżają się do bieguna kobiecego, podczas gdy w kulturach męskich jest większe zróżnicowanie między rolami przypisywanymi płciom. Na pierwszy rzut oka kraje Azji sytuują się zarówno na męskim (np. Japonia, Filipiny), jak i kobiecym wymiarze (np. Tajlandia, Korea Płd., Tajwan). Są też takie, w których oba wymiary są istotne (np. Malezja). A jak ma się sprawa w społeczeństwach Azji Środkowej?

Zanim padnie odpowiedź na to pytanie należy uzmysłowić sobie na czym polegają różnice pomiędzy kobiecym a męskim typem społeczeństwa. Tabela poniższa. zawiera zestawienie podstawowych odmienności obu typów społeczeństw.

Tabela 1. Podstawowe różnice pomiędzy kobiecym i męskim typem społeczeństwa (na podstawie: Hofstede 2000; Hofstede i Hofstede 2007)

\begin{tabular}{|c|c|c|}
\hline & Kobiece społeczeństwo & Męskie społeczeństwo \\
\hline 1. & $\begin{array}{l}\text { Narodowe nastawienie na opiekowa- } \\
\text { nie się innymi oraz na troskę o jakość } \\
\text { życia }\end{array}$ & $\begin{array}{l}\text { Narodowe nastawienie na pewność sie- } \\
\text { bie, zdobywanie pieniędzy i dóbr mate- } \\
\text { rialnych }\end{array}$ \\
\hline 2. & $\begin{array}{l}\text { Istotni są ludzie i przyjazne relacje } \\
\text { między nimi }\end{array}$ & Priorytet pieniądza i dóbr materialnych \\
\hline 3 & Pracuje się, żeby żyć & Żyje się, żeby pracować \\
\hline 4. & $\begin{array}{l}\text { Menedżerowie w organizacjach kie- } \\
\text { rują się intuicją i dążą do porozumie- } \\
\text { nia }\end{array}$ & $\begin{array}{l}\text { Menedżerowie } \mathrm{w} \text { organizacjach powinni } \\
\text { podejmować zdecydowane decyzje i być } \\
\text { asertywni }\end{array}$ \\
\hline 5. & $\begin{array}{l}\text { Ważna jest równość, solidarność i } \\
\text { jakość życia zawodowego }\end{array}$ & $\begin{array}{l}\text { Ważna jest sprawiedliwość, współza- } \\
\text { wodnictwo pracy i osiągnięcia }\end{array}$ \\
\hline 6. & $\begin{array}{l}\text { Konflikty są rozwiązywane na drodze } \\
\text { kompromisu i negocjacji }\end{array}$ & $\begin{array}{l}\text { Konflikty są rozwiązywane przez kon- } \\
\text { frontację siły }\end{array}$ \\
\hline
\end{tabular}


W społeczeństwie męskim występuje znaczny podział ról społecznych według płci. Natomiast w typie kobiecym - podział ten jest stosunkowo niewielki.

Rzeczywiste i statystyczne różnice biologiczne pomiędzy mężczyznami a kobietami są takie same na całym świecie, ale role społeczne przypisane tym dwóm płciom w różnych kulturach są tylko częściowo zdeterminowane ograniczeniami natury biologicznej (Hofstede i Hofstede 2007). Z tego wynika, że kultura w znacznym stopniu nakazuje członkom danego społeczeństwa podejmowanie takich, a nie innych działań czy zadań. I co ciekawe - zróżnicowanie typów następuje bez względu na to czy mówimy o społeczeństwach tradycyjnych, czy nowoczesnych. Hofstede i współpracownicy zbadali ponad 70 krajów świata i przeprowadzili klasyfikacje państw pod kątem wszystkich czterech ustalonych przez siebie wymiarów w obrębie porównań międzykulturowych. Znalazły się tam również państwa Azji - niestety zabrakło Nepalu, Tybetu i Bhutanu. Dlatego, by rozstrzygnąć wątpliwości, warto podjąć próbę choćby jakościowej analizy wymiaru męskości-kobiecości w omawianych krajach.

\section{Nepal}

Nepal wita emocjami kobiet i mężczyzn. Damskie kolorowe sari potęguje pierwsze wrażenie przyjazności i otwartości przy powitalnym, hinduistycznym ułożeniu dłoni jak do modlitwy, skinieniu głową i wypowiedzeniu pozdrowienia namaste („pokój z Tobą”). Stanowi to swoistą nagrodę za zderzenie się z nieznośnym smogiem na ulicach Kathmandu, zawierającym zarówno spaliny starych, dieslowskich silników, jak i smród ścieków wzbogaconych także w roślinne i zwierzęce szczątki. To dość swoisty konglomerat spowodowany specyfiką budowy wiecznie zielonej i wilgotnej Doliny Kathmandu, okolonej górami i wzniesieniami Himalajów oraz brakiem kanalizacji w stolicy.

Podstawowym zajęciem Nepalek jest praca w polu (75\% dochodu), hodowla zwierząt (głównie kóz, jaków, owiec i drobiu) i handel w miastach (Ross, Le Bas \& Bell 2009). Pola ryżowe wymagają niezwykłego poświęcenia i pieczołowitości $\mathrm{w}$ procesie sadzenia roślin i nawadniania. Mimo to ubrane w kolorowe sari kobiety zdobią zarówno wiejski, jak i miejski pejzaż - uśmiechnięte i pogodne. Wspomniany już brak kanalizacji i bieżącej wody w domach stwarza dość nietypowy uliczny obrazek kobiet myjących włosy $\mathrm{w}$ publicznych miejscach, wodą zaczerpniętą z miejskiej pompy, niejednokrotnie zdobionej starym ornamentem. Takie zbiorowe ablucje można niejednokrotnie spotkać na starówce Bhaktapur czy w Patanie. Sprawia to 
wrażenie zatrzymania się czasu w kołowrocie historii i poczucie mieszania się profanum z sacrum, gdy nieopodal stoi świątynia.

Na co dzień, poza strojami, warto podziwiać pracowitą krzątaninę kobiet na Thamelu, wśród licznych straganów albo też w zabytkowej części Bhaktapur, na placu Durbar. Charakterystycznym widokiem są kobiety noszące spore kosze na plecach, zamocowane długą przepaską na czole. Zazwyczaj w ten sposób transportują zielone rośliny uprawne bądź owoce. Praca ta praktycznie nie różni się od tej wykonywanej przez mężczyzn. Wydaje się więc, że pod tym względem trudno określić czy mamy do czynienia $\mathrm{z}$ typowo kobiecym czy męskim typem społeczeństwa, choć raczej z przewagą pierwszego rodzaju (Hofstede 2000). Na pewno w Nepalu bardzo istotne są przyjazne relacje społeczne i pozytywne nastawienie do ludzi.

Spośród omawianych tu kontekstów życia kobiet - Nepalki prezentują się na szczególnie kontrastowym tle. Zadbane, kolorowe ubiory i złote ozdoby często kłócą się z krajobrazem śmietnika na ulicach. Wydaje się, że dbałość o schludność otoczenia nie jest priorytetem tutejszej płci pięknej. Ważniejsza jest atmosfera jaką tworzą oraz ich dom rodzinny. Żyją na klepisku, w naszym, europejskim pojęciu - w niewykończonych domach, często ze sterczącymi z betonu ku górze drutami, co po części wynika ze specyficznych przepisów podatkowych. Opłata za parcelę z wykończonym domem często przekracza możliwości finansowe tubylczej ludności.

Osobnym, ale bardzo ważnym rozdziałem w historii nepalskich kobiet są heroinie zdobywające szczyty Himalajów. W Katmandu postawiono nawet pomnik Szerpijce, która jako pierwsza Nepalka weszła na Mount Everest. Taki rodzaj uznania jest dość nietypowy w patriarchalnym społeczeństwie nepalskim. Większość obelisków poświęcono bowiem znanym mężczyznom - głównie królom. I to jest z kolei dowód na dominację męskiego typu społeczeństwa, gdzie ważna jest sprawiedliwość, współzawodnictwo pracy i osiągnięcia, w przeciwieństwie do równości, solidarności i jakości życia zawodowego jako wartości kobiecych (Hofstede 2000). W tym kontekście należy też pamiętać o systemie kastowym, który reguluje życie mieszkańców, w tym i kobiet. Jego korzenie sięgają dawnych czasów i wpływów indyjskich widzianych tu na każdym kroku. Zasada funkcjonowania kast opiera się na dwoistości dharmy i karmy. Pierwsza kładzie nacisk na obowiązki jakim należy sprostać podczas całego życia, natomiast druga dotyczy wpływu, jakim konkretne działania implikują życie przyszłe, w nowym wcieleniu. Bramini i kszatrijowie, czyli kapłani i rycerze, stanowią najwyższe kasty i pełnią istotną rolę w społeczności. Wajšowie zajmują się produkcją, handlem i rolnictwem. Z kolei šudrowie stanowią najniższą kastę - chłopów. Jedną ze społecznych konsekwencji systemu kastowego jest za- 
kaz wchodzenia do kuchni oraz sanktuarium w domu członka wyższej kasty. Inną jest zakaz dotykania ciała, czy zawierania związków małżeńskich z przedstawicielem innej kasty. Należy jednak wspomnieć, że Nepal jest stosunkowo tolerancyjnym krajem, jeśli chodzi o pewne odstępstwa od reguł wspomnianego podziału. Jednak istniejące kasty i zasady regulujące ich funkcjonowanie są kolejnym argumentem za tym, by uznać Nepal za męski typ społeczeństwa, gdzie szczególną wartość stanowi pewność siebie, zdobywanie pieniędzy i dóbr materialnych (Hofstede 2000). Obecnie rząd Nepalu ma na celu zniesienie dyskryminacji kastowej wobec "nietykalnych". Dlatego też w 2009 roku dopłacał do obrzędu hinduskich par zawierających małżeństwa, gdzie mąż i żona pochodzą z różnych grup społecznych (http://www.money.pl/archiwum/wiadomosci_agencyjne/pap/ artykul/nepal;niemal;1000;euro;dla;malzenstw;miedzykastowych,45,0,491 053.html).

W Nepalu, podobnie jak w Indiach, małżeństwa są aranżowane przez rodziny młodych. W zależności od wyznania do ślubu dochodzi albo według hinduskiego, albo buddyjskiego obrządku. Zanim jednak do tego dojdzie, wiadomo, że wśród Newarów funkcjonują tzw. "rytuały przejścia” związane z najważniejszymi momentami życia. "Zaślubiny" Brahmie (zobacz: http://www.fototrip.pl/zdjecie,69138.html) oznaczają koniec beztroskiego dzieciństwa dla dziewczynek. Dla dziewcząt szczególnie barwną ceremonią są "zaślubiny" z hinduskim bogiem Wisznu, które odbywają się jeszcze przed okresem ich dojrzewania. W symboliczny sposób są odgrywane wszystkie obrzędy, które występują podczas realnego wesela. $\mathrm{W}$ ten sposób prawdziwy ślub ma miejsce później, bez przyszłego zagrożenia $\mathrm{w}$ postaci ewentualnego wdowieństwa. Księżycowy kalendarz jest wyznacznikiem wyboru terminu zaślubin, które zazwyczaj poprzedza występ orkiestry dętej i barwny uliczny korowód składający się z młodej pary i gości weselnych (Ross, Le Bas \& Bell 2009), ale też i każdej napotkanej osoby, która przyłączy się do orszaku. Współczesność przyniosła nowe rozwiązania w postaci garniturów dla mężczyzn i samochodów wiozących młodych do ślubu. Natomiast kobiety zachowały stary zwyczaj ubierania barwnych sari, potęgując tym samym efekt uroczystości. Młoda para w czasie rytuału zaślubin składa sobie przyrzeczenia oraz obdarowuje się nawzajem girlandami, pierścionkami itp. Odprawia się też pudźę i jadźnię̧ oraz odmawia modlitwy. Część oficjalna trwa łącznie ok. 7 godzin i oprócz małżonków uczestniczą w niej tylko członkowie ich najbliższej rodziny. Pozostała część zaproszonych na uroczystość gości urządza w tym czasie wesele.

\footnotetext{
${ }^{3}$ Obrzędy ofiarne.
} 
Jeśli chodzi o małżeństwo zdarzają się przypadki poligamii, np. u Tamangów żyjących w wyższych partiach Himalajów. Zdarzały się przypadki uprowadzenia czyjejś żony, a w zamian za to uiszczenia odpowiedniej kwoty dla załagodzenia sprawy (Ross, Le Bas \& Bell 2009). Ale zdarzają się też sytuacje odwrotne - na nepalskiej wsi, w dystrykcie Humla, leżącym pod granicą tybetańską, można spotkać kobietę, która ma trzech mężów-braci i nie może wyróżniać żadnego z nich. Każdy jest traktowany tak samo, z należytą atencją. Stary obyczaj poliandrii (wielomęstwa) wśród Szerpów został podyktowany względami ekonomicznymi. Gdyby każdy z braci poślubił inną kobietę, ziemia przekazywana $\mathrm{z}$ ojca na syna uległaby podziałowi, a więc rozdrobnieniu majątku. Trudniej byłoby żyć z tak skromnej spuścizny: im więcej dzieci, tym mniej pozostawałoby dla następnych pokoleń. Ponadto w przeszłości mężczyźni często przebywali z dala od domu, a zatem ten który pozostał z żoną roztaczał należytą opiekę nad gospodarstwem. Powyższe ilustracje obrazują z jednej strony męski, a z drugiej kobiecy typ społeczeństwa.

Bardzo ważnym elementem w łańcuchu społecznym Nepalczyków są dzieci - zazwyczaj bardzo kochane, ale jednocześnie od najmłodszych lat wdrażane $\mathrm{w}$ życie rodziny, pomaganie jej i w tryb pracy. Nawet najmłodsze, już 4-5 letnie maluchy dźwigają za matką dary ziemi, pomagają przy młodszym rodzeństwie, zwierzętach domowych czy w polu. To zupełnie inny system wychowywania niż w Europie. Nie wszystkim znany jest fakt, że potomstwo stanowi swoistą polisę emerytalną na starość. W Nepalu nie ma bowiem czegoś takiego jak ubezpieczenie emerytalne. Starzejący się rodzice mogą liczyć jedynie na opiekę ze strony swoich pociech. Wielopokoleniowość rodzin stanowi zatem ważne antidotum na starość, która w nepalskim społeczeństwie stanowi niepodważalną wartość. I to jest argument przemawiający za kobiecym typem społeczeństwa, kiedy to wartością naczelną jest opiekowanie się innymi oraz troska o jakość życia (Hofstede 2000).

To nie jedyny z ciekawszych systemów społecznych funkcjonujących w opisywanym kraju. Na północy żyje lud Thakali, który utworzył własną religię zawierającą zarówno hinduistyczne, jak i buddyjskie wątki, ale także udoskonalił sztukę wymiany i handlu (np. solą pomiędzy Tybetem a Indiami). Aktualnie uczestniczy on - również kobiety - we wszystkich sektorach życia publicznego: od budownictwa, polityki, poprzez biznes, aż do środowisk akademickich i artystycznych. Tajemnica tej ekspansji tkwi w bardzo ciekawym systemie dighur, który polega na zgromadzeniu określonej kwoty pieniężnej przez przyjaciół lub krewnych dla jednego członka grupy (Ross, Le Bas \& Bell 2009). Wybraniec wydaje pieniądze na cele określone przez siebie, według własnej woli - na co chce. Jedynym zobowiąza- 
niem takiej osoby jest włączenie się na następny rok w proces gromadzenia pieniędzy dla kolejnego szczęśliwca. Niestety, nie wszędzie tak sprawnie można pozyskać fundusze na naukę i trzeba zaznaczyć, że analfabetyzm jest powszechnym zjawiskiem w Nepalu - chociaż w większości szkolnictwo jest bezpłatne, to nie wszystkich rodziców stać na podręczniki i mundurki dla swoich pociech.

\section{Tybet}

Porównując życie tybetańskich kobiet z nepalskimi, to pierwsze wydaje się bardziej powściągliwe. Z racji opisanych wcześniej burzliwych losów politycznych Dachu Świata, trudno się dziwić nieufnym spojrzeniom, pewnemu rodzajowi smutku, który głęboko tkwi w ludziach. Tutaj kobiety są znacznie mniej ekspresyjne. Noszą też bardziej stonowane i grubsze stroje wykonane z wełny, ze względu na ostry, górski klimat i częste zmiany aury.

Na co dzień, na ulicy można spotkać mnóstwo medytujących przechodniów, którzy siedząc przed świątynią, na placach, czy nawet idąc, trzymają w ręku modlitewny młynek i wprawiając go w obrotowy ruch, kręcą w lewą stronę (zawsze zgodnie ze wskazówkami zegara) i wypowiadają im tylko znane słowa mantry. W Lhasie, stolicy Tybetu, na placu przed klasztorem Jokhang można spotkać pielgrzymów - zarówno kobiety, mężczyzn, jak i dzieci, młodych i starych - którzy dokonują żmudnego i czasochłonnego rytuału modlitewnego. Ślizgowym ruchem upadają przodem na kamienny chodnik, na ręce. Przyjmują w ten sposób pozycję leżącą na brzuchu, by po kilku sekundach powstać najpierw na kolana i z klęku wykonując płynny ruch, z powrotem znaleźć się $\mathrm{w}$ pionie. Niektórzy w tym celu rozkładają przed sobą maty lub przywiązują sobie na przedzie ciała rodzaj fartucha ze skóry. Inni trzymają $\mathrm{w}$ dłoniach kawałki drewnianych deseczek $\mathrm{z}$ opaską mocującą, by przy upadku zamortyzować uderzenie w podłoże. Obrządek ten wywołuje niezwykłe wrażenie, zwłaszcza wśród Europejczyków widzących go pierwszy raz. Efekt potęguje widok kobiet i dzieci, wkładających taki sam, ciężki wysiłek jak mężczyźni w całość modlitwy. Powyższy obrazek ilustruje równość tybetańskich kobiet i mężczyzn wobec religii, choć w kraju zaznacza się przewaga męskich klasztorów nad żeńskimi.

Jedynym w swoim rodzaju obrazem Lhasy jest zderzenie świata tybetańskiego z chińskim. Rdzenna ludność $\mathrm{w}$ większości zamieszkuje pilnie strzeżoną dzielnicę tybetańską, w której między 24.00 a 6.00 rano wprowadzono godzinę policyjną. O tej porze życie na ulicy zamiera. Patrole wojskowe są w ciągłym ruchu (nawet za dnia), a żołnierze trzymają palec na spuście broni. Gdzieniegdzie słychać policyjny gwizdek i ujadanie psów. 
Zdziwienie potęguje fakt, że po zmroku w dzielnicy, w zasadzie w centrum miasta, panuje $w$ domach i wokół nich mrok. Wielu mieszkańców po prostu nie stać na oświetlenie. Żyją jedynie z handlu i nie mogą być zatrudniani jako specjaliści. Zresztą brakuje takowych ze względu na brak dostępu do nauki. Kiedyś rolę wychowawczą i edukacyjną pełniły klasztory. Dzisiaj wiele $\mathrm{z}$ nich jest przepełnionych przebranymi $\mathrm{w}$ mniszą odzież figurantami - ochroną pobierającą opłaty za każde zdjęcie wykonane we wnętrzu świątyni. Święte księgi z historią wiary buddyjskiej i modlitwami leżą popakowane za szybą lub ażurem w niedostępnych zakamarkach półek i nikt z nich nie może korzystać. Tak umiera słowo pisane. Jedynym ratunkiem dla młodszego pokolenia jest tajna migracja przez Himalaje do Indii lub ustny przekaz rodziny. Ale Tybetańczycy to dumny naród, sprawiający wrażenie spokojnie oczekujących tego, co przyniesie przyszłość. Życie na co dzień toczy się dalej, by przetrwać. Opis ten wskazywałby na kobiecy typ społeczeństwa Tybetu, ze względu na podkreślanie wagi człowieka i przyjaznych relacji interpersonalnych. Do tego dochodzi poszanowanie opieki nad innymi oraz troska o jakość życia (Hofstede 2000).

Bliskie związki prowadzące do założenia rodziny są aktualnie ważnym elementem podtrzymywania tradycji i obrzędowości wśród Tybetańczyków. Termin ślubu jest wybierany według kalendarza tybetańskiego. Na znak gotowości do wstąpienia w związek małżeński dziewczęta zaplatają warkocze na głowach i zakładają kolorowe fartuchy - symboliczny sygnał dla przyszłego oblubieńca. Dziewczęta mają okazję spotykać się z chłopcami na zgromadzeniach publicznych, przy ognisku i tańcach. Zatwierdzenia wyboru ukochanego dokonuje wuj dziewczyny. Natomiast dzień przed ślubem wuj pana młodego przyjmuje prezenty. Panna młoda otrzymuje białego konia od swojego przyszłego męża, na którym pojedzie do niego w białej, wełnianej sukni. Towarzyszyć jej będą wuj i stryj, którzy też udzielają błogosławieństwa - młodym, członkom ich rodzin oraz domostwom. W obrzędowości tybetańskiej ślub się odbywa po uczcie weselnej. Takie patriarchalne podejście wskazuje na męski typ społeczeństwa (Hofstede 2000).

Z drugiej strony ciekawy ewenement dla Europejczyka stanowi zwyczaj chińskich kobiet Mosuo żyjących nad jeziorem Lugo, stosunkowo niedaleko od granicy z Tybetem, na linii prowincji Yunnan i Syczuan. W ich społeczności nie istnieje instytucja małżeństwa, można natomiast mówić o matriarchacie. Tamtejsze kobiety mogą znajdować sobie nawet po kilku partnerów i z nimi współżyć (Darewicz 2011). Korzenie tego obyczaju nie są tak naprawdę znane, choć być może geneza jest podobna do opisanej wyżej historii nepalskich Tamangów. Co ciekawe, kobieta Mosuo ma w obrębie wspólnego rodzinnego domostwa swoją własną sypialnię, tzw. kwiatową 
komnatę. Po zmroku u jej drzwi zjawia się wybranek, który wcześniej otrzymał zaproszenie $\mathrm{w}$ postaci umownego prezentu lub muśnięcia dłoni na znak przyjęcia zalotów. Nad ranem mężczyzna musi wrócić do swojego domu nie zauważony przez nikogo. Dlatego też w tamtejszym obyczaju jest noszenie obszernych kapeluszy przez „brzydką płeć”. Jeżeli kobieta uzna, że nie chce przedłużać związku, po prostu zamyka drzwi od sypialni i nikogo nie wpuszcza (op. cit.). Może z wyjątkiem nowego wybranka [...] Mamy więc niezbity argument przemawiający za typowo kobiecym charakterem społeczeństwa.

Kolejny opis potwierdza typ kobiecy - dzieci Tybetu stanowią ważne ogniwo $\mathrm{w}$ transmisji międzypokoleniowej. Wychowywane są $\mathrm{w}$ miłości, pieczołowicie, często noszone $w$ chuście na plecach matki. Problem pojawia się w wieku 3-4 lat, kiedy to rodzina staje przed dylematem edukacji swoich pociech, a której nie można oficjalnie dopełnić. Tak naprawdę nie ma wolności słowa ani religii. Wówczas wiele matek i ojców podejmuje desperacką decyzję o podróży dziecka przez Nepal w kierunku Indii, by nie przepadła spuścizna ich przodków. W 2010 roku minęła 50. rocznica utworzenia Tybetańskich Wiosek Dziecięcych (TCV) na ziemiach indyjskich, które są ratunkiem dla przetrwania świadomości narodowej młodych Tybetańczyków. Niestety często dochodzi do ingerencji w ten system, tak jak to miało miejsce w 2008 roku - gazeta "Tibet Daily" umieściła cytat następującego ostrzeżenia wystosowanego przez władze chińskie: „Obywatele posiadający dzieci studiujące za granicą we wspomnianych szkołach i klasztorach proszeni są o sprowadzenie ich do kraju w ciągu dwóch miesięcy. Wobec osób, które zastosują się do zaleceń w przewidzianym terminie, zostaną zastosowane, lub też nie, działania dyscyplinarne - w zależności od wagi sprawy" (zobacz: ratujTybet.org. 2008). Restrykcje mogą dotyczyć całej rodziny i powodować jej stopniową degradację, np. poprzez utratę pracy. Aktualnie w ośrodkach, które na terenie Indii rozłożone są na obszarze od Ladakh na północy, aż po Bulakuppe na południu kraju, znajduje się ponad 16178 małych Tybetańczyków (tcv.org.pl, 2009). Dla ich matek i ojców, ponowne spotkanie po kilkunastu latach jest rewolucyjnym przeżyciem, nie mogącym się równać innemu [...] Podany przykład stanowi ilustrację kontrastu pomiędzy chińskim, typowo męskim społeczeństwem, gdzie konflikty są rozwiązywane przez konfrontację siły a tybetańskim (kobiecym), które jako wartość ceni sobie rozwiązywanie napięć poprzez negocjacje i kompromis (Hofstede 2000). Swoją drogą taki scenariusz jest możliwy do realizacji dzięki dysproporcji zamożności i zaawansowania technicznego Chin w porównaniu do Tybetu. 


\section{Bhutan}

Mentalnie Bhutanki bardziej przypominają Tybetanki niż Nepalki. Nic dziwnego - zamieszkują tereny Tybetu, z których zostało wyodrębnione państwo Bhutanu. Na skali ekspresji emocji mogłyby zajmować miejsce pośrednie pomiędzy kobietami opisywanymi w poprzednich podrozdziałach. Jeszcze do niedawna Bhutan (Drukjul = Królestwo Smoka), zwany też azjatycką Szwajcarią, spełniał warunki mitu o tajemniczym i niedostępnym królestwie, aktualnie odwiedzanym przez nie więcej niż kilka tysięcy turystów rocznie. W 1999 roku wprowadzono tu internet i telewizję. Od czasu wkroczenia pełną parą cywilizacji, kraj rozwija się w błyskawicznym tempie, co nie pozostaje bez wpływu na życie całego społeczeństwa. Powstaje wiele nowych hoteli, domów i restauracji. W latach 70. rozpoczęto utwardzanie dróg, dzięki czemu można się wygodniej poruszać, zwłaszcza po zachodniej części kraju. „Kiedy pojawiły się u nas samochody, ludzie myśleli, że to wielkie zwierzęta. Przynosili im karmę, by miały siłę do dalekiej drogi" - o życiu w Bhutanie opowiada królowa tego niezwykłego państwa (Kim 2011).

Dlatego też ciekawym zjawiskiem obserwowanym $w$ tym regionie jest zderzenie nowoczesnych wynalazków cywilizacji z konserwatywną tradycją. Po wylądowaniu uderza fakt, że w terminalu lotniczym cała obsługa nosi stroje swoich przodków. Kobiety odziane są w kirę - kobiecą suknię do kostek spiętą na ramionach, oraz rodzaj żakietu, często o fantazyjnych, barwnych wzorach, zapinanego w pasie złotą lub srebrną broszą. Mężczyźni z kolei noszą gho - rodzaj cienkiego płaszcza do kolan, przepasanego $\mathrm{w}$ połowie długości, posiadającego białe, szerokie mankiety wywijane od środka na zewnątrz. Na nogach noszą czarne podkolanówki oraz eleganckie, skórzane buty. Z rzadka (np. w czasie narodowych lub lokalnych świąt) nakładają tradycyjne, zazwyczaj czarno-białe, pięknie zdobione kolorowymi tasiemkami filcowe kozaki do kolan, z wywiniętymi fantazyjnie noskami przyczepionymi do podbicia. Na specjalne okazje mężczyźni opasają się przez lewe ramię trzymetrowym szalem zwanym kabne. Jego kolor jest istotną informacją o statusie społecznym: szafranowy nosi król, pomarańczowe - członkowie rządu, niebieskie - Rada Doradcza Króla, czerwone członkowie rodziny królewskiej, zielone - sędziowie, białe - reszta mieszkańców państwa. Stroje te zachwycają stonowaniem i elegancją. Kobieta i mężczyzna idący ulicą wyglądają bardzo uroczyście, niczym przygotowani do jakiegoś ważnego obrzędu. I rzeczywiście widać to w całej okazałości, choćby przy okazji festiwalu ceczu ku czci Guru Rinpocze, by upamiętnić jeden z jego bohaterskich czynów. Zazwyczaj tłum gromadzi się wówczas 
na dziedzińcu jednego z dzongów, czyli swoistych fortec-klasztorów, żeby oglądać wielogodzinne religijne tańce.

Opisana hierarchia władzy oraz znaczenie symboliki kolorów w męskim stroju może wskazywać na męski typ społeczeństwa. Nic bardziej mylnego - otóż pomimo tego, że mamy do czynienia z rządami monarchii konstytucyjnej, panuje tu wyjątkowa troska o jakość życia. Niezwykła dbałość ostatnich dwóch królów - Singye Wangchucka i jego syna Jigme Khesara Wangchucka - o poddanych przejawia się na każdym kroku: w systemie opieki zdrowotnej, szkolnictwie, w trosce o kulturę, czy wreszcie o spuściznę narodową. Jak podaje Population and Housing Cenzus Report z 2005 roku ochrona medyczna obejmuje $98 \%$ ludności. Z kolei liczba uczniów i studentów wynosi ok. 145 i pół tysiąca, nauczycieli 5772. W obliczu tego współczynnik dzieci uczęszczających do szkoły podstawowej wynosi $84 \%$, a współczynnik analfabetyzmu wśród dorosłych - 60\% (Pommaret 2008). Przytoczone statystyki rosną znacznie prężniej niż w społeczeństwach Nepalu czy Tybetu. Taka opieka państwa nad swoimi mieszkańcami zdecydowanie wskazuje na jego opiekuńczość i ferowanie wartości kobiecych, gdzie pracuje się, żeby żyć i jakość tego życia jest stawiana na pierwszym miejscu (Hofstede 2000). Nie bez powodu Bhutan nazwany jest „Podniebnym Królestwem" - decyduje o tym nie tylko wysokogórskie położenie i klasztory usytuowane wysoko, $\mathrm{w}$ trudno dostępnych miejscach, ale także deklaracja ponad $45 \%$ mieszkańców, że są bardzo szczęśliwi, a $51 \%$, że są „tylko" szczęśliwi. Praktycznie jak w Niebie [...] Nie na darmo ważnym symbolem malowanym na fasadach bhutańskich domów są olbrzymie, stylizowane penisy, zgodnie z szesnastowiecznym obyczajem odstraszające złe moce

W bezpośrednim zetknięciu się z mieszkańcami Królestwa Smoka można wyczuć pewną ciekawość i stonowaną otwartość. W porównaniu do Tybetu znacznie więcej tu śmiejących się twarzy, choć nie aż tak, jak w Nepalu. Na pierwszy rzut oka widoczna jest znaczna śmiałość młodszego pokolenia, dobrze wyedukowanego, władającego językiem angielskim. Bhutanki odnajdują się w nowej rzeczywistości: są nowoczesne i uczą się emocji „na zewnątrz". W kraju, w którym przez wieki obracały się wśród "swoich", zetknięcie się z Europejczykiem powoduje wzbudzenie rytuału uśmiechania się - dość umiarkowanego i trochę nieśmiałego u starszych kobiet, a odważnego, wyzwańczego w połączeniu z angielską konwersacją u młodszych dziewczynek.

Poza szczęściem miłość odgrywa istotną rolę w życiu mieszkańców Bhutanu. W przeciwieństwie do nepalskich „rytuałów przejścia” w kulturze bhutańskiej nie ma szczególnych ceremonii wyznaczających okres dorastania. Natomiast ważnym aktem zarówno dla kobiety, jak i mężczyzny jest 
małżeństwo, które można zawrzeć po prostu formalnie albo też z obfitą otoczką ceremonialną, w zależności od statusu pary lub okoliczności w jakich się poznali (Pommaret 2008). W sumie błogosławieństwo rodziców liczy się niezależnie od tego, czy para poznała się z miłości, czy zaaranżowano jej spotkanie np. w zaprzyjaźnionej rodzinie. Co istotne, nawet $\mathrm{w}$ tym drugim przypadku ważna jest zgoda obu partnerów na zawarcie ślubu. Astrolog wyznacza datę ceremonii, która $w$ bogatych rodzinach stanowi nie lada wydarzenie. Pan młody idzie wówczas ze swoimi przyjaciółmi po pannę młodą i przyprowadza ją razem $\mathrm{z}$ towarzyszami do swojego domu. Tam czeka już rodzina, witając narzeczonych miseczką mleka i wody, które symbolizują pomyślność na przyszłość. Rozpoczyna się ceremonia marczangu. Młodzi siadają wśród mnichów, którzy dokonują obrzędów ślubnych. Jednak ceremonia religijna nie ma wartości sakramentu, jak to się dzieje w przypadku hinduistycznego rytuału w Nepalu. Następnie para wymienia pomiędzy sobą pucharki z alkoholem i publicznie ogłasza się, że właśnie zostali mężem i żoną. Rodzina i zaproszeni goście obdarowują młodych prezentami oraz ważnym symbolem - białymi szalami, symbolizującymi błogosławieństwo i szczęście na powitanie. Całość zwieńcza wieczorna impreza z tańcami, posiłkiem i alkoholem (op. cit.). Opis ten również potwierdza kobiecy charakter bhutańskiego społeczeństwa: ważni są tu ludzie i przyjazne relacje między nimi (Hofstede 2000). O wyborze partnera na całe życie decydują obie strony.

Małżeństwo w Bhutanie staje się też stanem faktycznym, gdy przedstawiciele uboższej warstwy społecznej chcą po prostu ze sobą zamieszkać. W tym celu nie muszą wypowiadać żadnych szczególnych słów czy przysięgi. Od niedawna istnieje prawny obowiązek rejestrowania zawartego ślubu, jednak nie wszyscy jeszcze oswoili się z tą zmianą i rzadko praktykowana jest ta procedura. Co ciekawe - dość powszechne są rozwody, ale jeśli kobieta domaga się rozejścia, jej nowy partner jest zobowiązany zapłacić poprzedniemu odszkodowanie (op. cit.). Nowo narodzone dzieci są w domach Królestwa Smoka witane z wielką radością. Po odwiedzinach rodziny następuje lhasang, czyli ceremonia oczyszczająca, po której z kolei przychodzą przyjaciele z darami, często pochodzenia naturalnego - jajami, ryżem bądź kukurydzą (na wsi) albo też ubrankami i pieluszkami (w miastach), czasami pieniędzmi. Zwyczajowo obcym nie wolno głaskać główki dziecka, ponieważ jest ona siedliskiem energii. W tym czasie, dla wzmocnienia, matkę poi się odżywczą mieszanką ciepłego alkoholu (!), masła i jajek. Podobnie też resztę gości. A zatem jest dosyć wesoło [...]

Wielkim wydarzeniem 2011 roku był ślub młodego króla Jigme Khesara Wangchucka, który zakochał się w 8-letniej dziewczynce, napotkanej dawno temu przy ognisku. Już wówczas poprzysiągł sobie, że Jetsun Pema, 
„dziewczyna z ludu", córka pilota zostanie jego małżonką. 13 października 21-letnia Panna Młoda i 31-letni Pan Młody ziścili swoje marzenia w siedemnastowiecznej fortecy-klasztorze (dzongu), w dawnej stolicy kraju Punakha. Ceremonia była zamknięta i skromna - obyło się bez zaproszenia koronowanych głów ze świata („Gazeta Wyborcza” 2011). Zdjęcia z tego uroczystego dnia można oglądać na stronie: http://www.slubclick.com/ report/krolewski-slub-jak-z-bajki-w-bhutanie.html.

Przytoczone powyżej opisy nie rozstrzygają jednoznacznie czy wspomniane państwa mają typowo męski, czy raczej kobiecy charakter. Typy władzy w Nepalu czy Bhutanie wskazują na ten pierwszy, ale z drugiej strony zwyczaje związane z poliandrią wśród wysokogórskich ludów Nepalu, czy troska o członków narodu w Bhutanie i dość nietypowe, „wielkoduszne" rządy przemawiałyby za kobiecym typem. Jeszcze trudniej orzec w sprawie Tybetu, gdzie mamy przykład państwa w państwie. Gdyby rozpatrywać przypadek samego narodu tybetańskiego, przytoczone argumenty przemawiają za kobiecym typem społeczeństwa.

Ponieważ powyższa analiza nie dostarcza zdecydowanych rozstrzygnięć na temat klasyfikacji analizowanych narodów na męskie i kobiece, należałoby się zastanowić czy religia i jej wierzenia wnoszą nowe fakty do zaistniałego dylematu.

\section{WIARA I RELIGIA A ŻYCIE KOBIET}

\section{Hinduizm}

Jak się okazuje, podział na typy społeczeństwa dokonany przez Hofstede (2000) ma swoje odzwierciedlenie $w$ wierzeniach i religii opisywanych kobiet. Cechą wspólną porównywanych tu krajów jest fakt, że religia wyznacza rytm życia ich mieszkańców. Na przykład opisywane wcześniej nepalskie „rytuały przejścia” począwszy od urodzenia po części nawiązują do zaślubin z bogami, aż do obrzędu pogrzebowego, gdzie prochy zmarłych sypane do rzek będących dopływami Gangesu mają zapewnić im ponowne odrodzenie.

"Człowiek jest z natury zwierzęciem religijnym" - tak Spilka, Hill i Hood (2009) konstatują syntetyczne wyjaśnienie genezy ludzkich wierzeń (por. Bering 2006). Sugerują przy tym immanentny charakter religijności jako danej człowiekowi konstytucjonalnie (por. Moskovitz 2005; Bering 2010; Skrzypińska 2012). Nepal to konglomerat religijny. Spotykają się tutaj zarówno religia hinduistyczna, jak i filozofia buddyjska - obie należące do tzw. religii dharmicznych, powstałych z braminizmu na subkontynencie indyj- 
skim, a uznające prawo karmy i reinkarnację. I co ciekawe, mamy w tym przypadku do czynienia z jednym z niewielu miejsc na ziemi o tak wysokiej tolerancji, gdzie nie przeszkadzają sobie wyznawcy żadnej z wiar. Jednym z czynników decydujących o takim stanie rzeczy może być historia hinduizmu, który włączył do swojej religii wątek narodzin Sidharthy, późniejszego Buddy. Ponadto Nepalczycy, jak już wspomniano, są bardzo pogodnym i gościnnym narodem, o czym świadczy choćby przyjęcie wielu represjonowanych imigrantów z Tybetu.

Wyznawcami hinduizmu jest ponad miliard ludzi. Jednak celem niniejszego artykułu nie jest prezentacja religii sensu stricto, ale zwrócenie uwagi na obszary związane z życiem i rolą kobiet. Dlatego też przywołane zostaną jedynie najważniejsze cechy wspólne tradycji hinduistycznej, bez względu na bogactwo jej odłamów. Oto one:

1. Szacunek dla świętych ksiąg Wed, z których czerpana jest cała wiedza na temat funkcjonowania świata.

2. Wiara w reinkarnację, dającą szansę na ponowne wcielenie i lepsze życie, co zależy od jakości uczynków. Daje nadzieję w obliczu ziemskich trudności, zwłaszcza na terenach objętych nędzą i chorobą.

3. Wiara w prawo akcji i reakcji (karma), które tłumaczy przyczynę i skutek wydarzeń. W konsekwencji dla przyszłości człowieka istotny jest każdy uczynek. Nie ma tu miejsca na akt spowiedzi świętej, która oczyszcza duszę z popełnionego grzechu. Wszystko zostanie policzone i złoży się na jakość przyszłego wcielenia.

4. Dążenie do wyzwolenia, różnie rozumianego przez poszczególne odłamy. Potęguje wiarę $\mathrm{w}$ kres cierpienia. Stanowi ulgę w codziennych bolączkach.

Powyższe dogmaty wiążą się z historią stworzenia świata przez Brahme oraz z rządami Wisznu, bóstwa wszechobejmującego wszystkie dusze i sześć doskonałości, a także Śizw - symbolizującego unicestwiający i odnawiający aspekt boskości. Natomiast zarówno dla nepalskich hinduistów, jak i zamieszkujących inne obszary Azji, szczególne znaczenie mają dwa wcielenia Wisznu - Rama i Kriszna - nieodłącznie związane z kobiecym wątkiem w opisywanej religii. Rama opisywany w Ramajanie (największej azjatyckiej epopei epickiej), to bohater nieskazitelny: odważny, szlachetny i cnotliwy. Podobnie jak jego żona Sita - doskonała, odważna i lojalna małżonka. Historia mówi o ich wyprawie do lasu i porwaniu Sity przez demona Rawana do kryjówki na wyspie Lanka (dzisiejszy Cejlon). Wówczas to Rama zwraca się o pomoc do plemienia małp oraz do ptaka, legendarnego wierzchowca Wisznu. Wspólnie uwalniają Site i zabijają demona. Wychodzi na jaw wierność żony Ramy pomimo zabiegów Rawany. Swoje poświęcenie kobieta udowadnia, wchodząc w ogień i wydostając się z płomieni nietknię- 
ta (Ross, Le Bas, \& Bell 2009). Do dzisiaj w Nepalu czci się owo wydarzenie, a postać Sity jest wzorem cnót dla nepalskich kobiet. To jeden z przykładów duchowości, która ukierunkowuje myślenie, emocje i działanie człowieka. Buduje rodzaj postawy wobec życia, ściśle wytyczonej przez religię z jej moralnym kodeksem (por. Shweder, Much, Park, \& Mahapatra 1997; Skrzypińska 2012). Ta opowieść uzmysławia, że Sita - jako posłuszna mężowi - wchodzi do ognia. Fakt ten od tej pory wyznacza rolę kobiety u boku męża, co kultywuje hinduistyczna tradycja.

Bardzo wyrazistą egzemplifikacją uznania dla kobiety religii hinduistycznej jest kult bogini Dewi, zwany Śaktyzmem. Śaktowie skupiają się na oddawaniu czci żeńskiemu aspektowi Boga - twórczej energii Śakti, personifikowanej pod postacią Bogiń - małżonek Bogów. Współcześnie w Nepalu żyje bogini Kumari Dewi uznawana za inkarnację bogini Taledźu pod postacią dziewczynki, której nie wolno fotografować. Ale hinduistyczna religia obfituje również $\mathrm{w}$ sprzeczności. Otóż z drugiej strony obrządek pogrzebowy nie pozwala kobiecie na bezpośrednie uczestnictwo w kremacji zwłok osoby zmarłej. A jeszcze do końca XIX wieku funkcjonował aktualnie zakazany obrządek palenia żywej żony wraz z umarłym mężem na stosie sati. Jeśli chodzi o społeczne konsekwencje wiary, w Upaniszadach świętych księgach hinduizmu - można znaleźć wskazania do wspomnianego wcześniej podziału na kasty, który istotnie rzutuje na życie kobiet i mężczyzn.

Powyższe przykłady stanowią ilustrację tezy o wadze procesów poznawczych w kreowaniu religii. Jak zauważył Guthrie (2001) bogowie, demony, duchy i inne postaci są częścią "człekopodobnych" istot (humanlike beings), będących wyobrażeniami związanymi z interpretacją tego jak funkcjonuje świat. Wydaje się, że postać bogini Kumari Dewi może być właśnie takim ucieleśnieniem kobiecych przymiotów, służącym podtrzymaniu tożsamości jej wyznawczyń oraz ich poczucia własnej wartości. Religia dodatkowo daje poczucie więzi wewnątrzgrupowej, podtrzymując tym samym poczucie bezpieczeństwa jej wyznawców. W opozycji do tego, hinduizm często podkreśla $\mathrm{w}$ wierzeniach przewagę męskiego pierwiastka oraz jego kluczową rolę dla rodzaju ludzkiego. Wydaje się wręcz, że jest go znacznie więcej niż kobiecego - choćby w świętych księgach.

\section{Buddyzm}

W buddyźmie religijną tożsamość kultywują klasztory skupiające mnichów. Istnieją klasztory żeńskie, choć nadal dość skąpo rozpowszechnione na terenie Tybetu i Bhutanu (tutaj doskonali się ok. 600 mniszek; Pommaret 
2008). Warunkiem przystąpienia do społeczności klasztornej jest ogolenie głowy, czyli w przypadku kobiet pozbawienie się istotnego dla własnego wizerunku atrybutu. Inne wartości stają się wówczas ważne, związane z duchowym samodoskonaleniem i poszukiwaniem oświecenia.

W kulturze buddyjskiej wizerunek kobiety jawi się jako przeciętny. Jej rolą jest doświadczanie codziennego życia, usiłowanie zrozumienia nauk Buddy i wreszcie stanie się świadomą duchowej natury ludzkiej egzystencji. $W$ zasadzie przeznaczeniem kobiety nie jest bycie uczoną, duchowną czy filozofem. To raczej domena mężczyzn, którzy swoją życiową ścieżkę wiedzy podporządkowują dążeniu do oświecenia. U kobiet to raczej ból i cierpienie stanowią klucz do samodoskonalenia (Boehm 2004).

Buddyzm stanowi bardziej system filozoficzno-etyczny niż religię, ponieważ brakuje w nim pojęcia boga osobowego (por. duchowość a religijność w Saucier i Skrzypińska 2006). Istnieje za to wiara w siły nadprzyrodzone. Zakłada poszanowanie życia w każdej postaci i równość pomiędzy kobietą a mężczyzną. Teoretycznie kobietom łatwiej byłoby osiągnąć oświecenie, gdyż ich biologiczna funkcja, czyli możliwość rodzenia dzieci ukierunkowuje zainteresowania i energię. Często poświęcają się dzieciom i rodzinie bez reszty, nie myśląc o sobie. W ten sposób wyrzekają się własnego ego, czyli głównej przeszkody, która w konsekwencji nigdy nie urasta do poziomu obserwowanego u mężczyzn. Niestety ta sama biologia plus uwarunkowania społeczne sprawiają, że przestają szukać innego celu w życiu niż rodzina, bo to ona staje się głównym celem. I tutaj pojawia się większa szansa dla mężczyzn - im łatwiej dostąpić stanu oświecenia, w związku z możliwością pełnego oddania się procesowi samodoskonalenia.

$\mathrm{Z}$ hinduizmem buddyzm zgadza się $\mathrm{w}$ dwóch ważnych kwestiach: karmie $^{4}$ i reinkarnacji. Przy czym buddyści znacznie rygorystyczniej przestrzegają zakazu zabijania zwierząt. Niestety współcześnie, dla tzw. dobra turystyki zwierzęta hodowlane są wywożone do Indii i tam pozbawiane życia, by w postaci półproduktu powrócić na restauracyjne stoły do swojej ojczyzny. Natomiast karma i reinkarnacja dotyczą zarówno kobiet, jak i mężczyzn. Co ciekawe - w hinduizmie istnieje przekonanie, że kobieta się rodzi sobą, ponieważ wystarczająco już, na swój poziom rozwoju, nauczyła się być mężczyzną i teraz czas na pracę nad wcieleniem kobiecym - ma się nauczyć żyć jako kobieta. Z kolei mężczyzna jest sobą dlatego, że wystarczająco dobrze nauczył się być kobietą i teraz ma szansę nauczyć się być

\footnotetext{
${ }^{4}$ Buddyjskie pojmowanie karmy różni od innych religii to, że skutek czynu nie jest tu z góry ustalony (tak jak to się ma np. w protestantyzmie i naukach o predestynacji). Określony czyn nie ma zdeterminowanego skutku, który musi zaistnieć. Takie pojmowanie karmy obala mit fatalizmu, który często niesłusznie przypisuje się buddyzmowi.
} 
mężczyzną. Wygląda na to, że oba pierwiastki rodzajowe uzupełniają się w ten sposób.

Wymiar doktrynalno-filozoficzny buddyzmu, poza wiarą w karmę i reinkarnację, budują Cztery Szlachetne Prawdy (por. Kalmus, 2009):

1. Pierwsza Szlachetna Prawda o Cierpieniu: „Narodziny są cierpieniem, starzenie się jest cierpieniem, śmierć jest cierpieniem. Smutek, lament, ból, zgryzota i rozpacz są cierpieniem. Towarzystwo nielubianych jest cierpieniem, rozłąka z ukochanymi jest cierpieniem. Niemoc uzyskania tego co się chce jest cierpieniem".

2. Druga Szlachetna Prawda o Przyczynie Cierpienia: przyczyną cierpienia jest pragnienie. Realny świat, to świat złudzeń nazywany maja, który przeszkadza w dotarciu do prawdy. Gdyby ludzie do niej dotarli, nie doznawaliby cierpienia, gdyż wszelkie psychiczne cierpienie jest efektem niewłaściwego (zwykle dualistycznego i oceniającego) widzenia świata.

3. Trzecia Szlachetna Prawda o Ustaniu Cierpienia: ustanie cierpienia to całkowite zaniknięcie i ustanie, wyrzeczenie się, zaniechanie, wyzwolenie, puszczenie pragnienia, ponieważ jego praprzyczyną jest uwikłanie się w namiętności.

4. Czwarta Szlachetna Prawda o Ścieżce Prowadzącej do Ustania Cierpienia: drogą do ustania cierpienia jest Szlachetna Ośmiostopniowa Ścieżka - właściwy pogląd, właściwe postanowienie, właściwa mowa, właściwe działanie, właściwy żywot, właściwe dążenie, właściwe skupienie, właściwa medytacja. Głównym celem buddystów jest transformacja swojego umysłu, a medy tacja jest głównym środkiem ku temu celowi.

Wszystkie cztery prawdy są przeznaczone do doskonalenia się zarówno kobiet, jak i mężczyzn. Według nauk buddyzmu praktycznie wszystkie czujące istoty podlegają samsarze („niekończącej się wędrówce”): po śmierci, w zależności od nagromadzonej karmy, przechodzą na inny poziom egzystencji (przyjmują nową formę, przeżywając nowe narodziny). Nieodłącznym elementem samsary jest cierpienie. Co prawda życie na „wyższych" poziomach egzystencji jest szczęśliwe, jednak nawet tam występuje nieuchronna śmierć oraz powrót na "niższe” poziomy. Stąd też jedynym sposobem na zakończenie cierpienia jest wyzwolenie się z tego cyklu poprzez osiągnięcie nirwany - ustanie wszelkiego pragnienia, swoistego stanu nicości.

I to stanowi klucz do szczęścia ostatecznego, choć rozumianego zupełnie inaczej niż w znaczeniu kultur zachodnich. Dlatego też na ulicach, przy stupach lub czortenach ${ }^{5}$, zarówno w Nepalu, Tybecie, jak i w Bhutanie, spot-

5 Typ sakralnej budowli buddyjskiej. W europejskim pojęciu, w zależności wielkości, można je przyrównać do czegoś w rodzaju grobowca (potężne) lub przydrożnej kapliczki (mniejsze). Stanowią miejsce modlitw. W największej w Nepalu stupie Boudhanath w Kat- 
kać można rzesze modlących się, którzy kręcą modlitewnymi młynkami, wypowiadając słowa mantry na każdy dzień lub na specjalne okazje. Daje to wyciszenie i wewnętrzny spokój. I rzeczywiście widoczny jest efekt behawioralny tych poczynań. Widać to w skupieniu i zamyśleniu twarzy. Światowe badania dowodzą, że osoby medytujące znacznie szybciej dochodzą do zdrowia i łatwiej przechodzą proces interwencji terapeutycznej (por. Koenig 1994; Heszen-Niejodek 2003; Grzymała-Moszczyńska 2004; Griffith, Griffith 2008; Krok 2008).

Z psychologicznego punktu widzenia bardzo ciekawym wydaje się buddyjski pogląd głoszący, że nie ma nic niezmiennego, co mogłoby przechodzić do następnego życia. Nie ma żadnego wiecznego osobowego "ja”, nawet "duszy", w przeciwieństwie do wierzeń hinduistycznych. Za tym poglądem podąża tradycja buddyjskiego obrzędu pogrzebu o bardzo złożonych rytuałach, trwających od 7 do 49 dni. Kiedy umiera człowiek, należy jak najszybciej wezwać mnichów, by dokonali rytuału wyprowadzenia świadomości z powłoki cielesnej. W tym celu odczytywana jest Księga Umartych, która ukierunkowuje zmarłego $\mathrm{w}$ wędrówce świadomości i wyjaśnia mu jej wizje (Pommaret 2009). Potem przez jakiś czas przychodzący goście składają rodzinie kondolencje, pieniądze, białe szale, a także podawane są posiłki zmarłemu. $W$ końcu odbywa się spalenie zwłok, podczas którego zgromadzeni modlą się o dobrą inkarnację dla odchodzącego. Po kremacji prochy rozsypuje się do rzeki lub miesza z gliną, by powstały wotywne tabliczki (op. cit.). W miejscu rozsypania prochów wbija się maszty z białymi flagami modlitewnymi, trzepoczącymi na wietrze. Przejeżdżający obok, mijający taki widok mają świadomość, że są blisko miejsca swoistego cmentarza. Innym zwyczajem mieszkańców Wyżyny Tybetu jest tzw. niebiański pochówek. Zmarłego wnosi się na zbocze wysokiej góry i pozostawia dzikim ptakom, by zapewnić cykl życia.

\section{PODSUMOWANIE}

Powyższe refleksje stanowią zaledwie impresję, wstęp do szerszych rozważań na temat codziennego i duchowego życia kobiet państw Środkowego Wschodu. Ich celem jest przybliżenie informacji o tak mało znanym świecie, ze względu na stosunkowo słaby dostęp do niektórych wiadomości. Z przedstawionej analizy wynika, że pomimo względnego sąsiedztwa terytorialnego, codzienne życie opisanych kobiet różni się istotne, ze względu na wiele czynników - głównie naturalnych, społecznych, ekono-

mandu spoczywają szczątki Buddy. Dla buddystów stupa jest materialną reprezentacją doskonałego oświecenia. W Bhutanie używa się nazwy czorten. 
micznych, politycznych i religijno-kulturowych (w tym duchowych). Najwyższa jakość życia kobiet w porównywanych krajach występuje w Bhutanie, ze względu na wysoki dochód narodowy, ale też i specyficzną filozofię oraz proces podtrzymywania tradycyjnych wartości, pomimo jednoczesnego wdrażania postępu cywilizacyjnego. Większość opinii publicznej uważa, że Królestwo Smoka stanowi ewenement w skali światowej.

Poza bogactwami naturalnymi, niezaprzeczalnie $\mathrm{w}$ tym sukcesie ma swój udział wielowiekowa izolacja terytorialna stwarzająca idealne warunki do rozwoju specyficznej wspólnoty jaką jest naród bhutański. Niestety, przeciwne wnioski nasuwają się w przypadku ludności Tybetu. Ze względu na trudną sytuację polityczną, jakość życia codziennego, a w tym duchowego, jest poważnie zagrożona i nie widać realnej perspektywy jej poprawy. Wydaje się również, że życie religijne na tym obszarze stanowi istotny czynnik psychologiczny, narodowościowy, spajający kulturę Tybetu i pozwalający trwać w tej patowej sytuacji. Wielu autorów wskazuje na dobroczynną rolę duchowości, $\mathrm{w}$ tym religii, indywidualnego poglądu na świat czy wierzeń w podtrzymaniu nadziei na przyszłość (np. Skrzypińska 2002), obronie własnej tożsamości (Greenberg, Pyszczynski i Solomon 1986), ochronie przed lękiem spowodowanym świadomością własnej śmiertelności (op. cit.). Wiara w pewien ustalony z góry porządek świata, jaki oferuje religia (Shweder, Much, Park, \& Mahapatra 1997, s. 147), pozwala wierzyć $\mathrm{w}$ lepsze jutro.

Rodzajowy wątek, w postaci klasyfikacji typów społeczeństw na męskie i kobiece według Hofstede, wydaje się nie do końca rozstrzygnięty w analizowanych krajach. Trudność polega na tym, że zarówno w Nepalu, Tybecie, jak i Bhutanie można odnaleźć wzorce tendencji pasujących zarówno do męskich, jak i kobiecych typów społeczeństw, z akcentem położonym na to ostatnie. Zresztą sam Hofstede wskazuje na to, że istnieją państwa znajdujące się w środkowej części opisywanego wymiaru (np. Pakistan, Malezja, Singapur - Hofstede, i Hofstede 2007, s. 137). A zatem, według niniejszej analizy, przewaga męskich elementów ujawnia się $\mathrm{w}$ postaci kastowego podziału w Nepalu, choć i na tym polu dochodzi do reform. Z drugiej strony, społeczeństwo nepalskie niczym państwo $\mathrm{w}$ państwie, $\mathrm{z}$ powodu słabych warunków ekonomicznych, utworzyło własny system ubezpieczenia emerytalnego dla starych ludzi - wielodzietność gwarantującą wielopokoleniowość, a tym samym poczucie bezpieczeństwa, utrzymanie i opiekę. To samo dotyczy Tybetu, choć tam nie ma systemu kastowego, a pokojowe i kompromisowe nastawienie do ludzi, stawianie na równość i solidarność przemawiają za kobiecym typem społeczeństwa. Z drugiej strony - gdyby nie inwazja Chin, to najprawdopodobniej tybetańskie rządy teokratyczne bardziej opierałyby się na męskim wymiarze. W Bhutanie większość argu- 
mentów również przemawia za kobiecym typem. Zwłaszcza że dba się tu w wyjątkowy sposób o jakość życia wszystkich obywateli. Pomimo ustanowienia monarchii konstytucyjnej, odwiedzając ten kraj ma się wrażenie pobytu w państwie idealnym.

Co ciekawe - analiza systemu wierzeń wszystkich trzech państw również nie dała jednoznacznych dowodów przemawiających za kobiecym bądź męskim typem społeczeństwa (może z lekką przewagą męskiego). Natomiast nie ma wątpliwości co do Chin, które już przez Hofstede zostały zaklasyfikowane jako typ męski.

Na pewno wspólnym mianownikiem niniejszych rozważań jest wniosek dotyczący ponadkulturowej uniwersalności wierzeń, które $\mathrm{w}$ wielu społeczeństwach, nie tylko azjatyckich, wyznaczają codzienny rytm życia, nadając mu specyficzny, niepowtarzalny koloryt. Wydaje się, że opisana różnorodność, pomimo codziennego trudu i ciężkiej pracy, daje nepalskim, tybetańskim, a zwłaszcza bhutańskim kobietom specyficzne szczęście - naznaczone rysem tradycji, w tym duchowości.

\section{BIBLIOGRAFIA}

Bem S.L. (2000), Męskość, kobiecość. O różnicach wynikających z ptci. Gdańsk, GWP Bering J.M. (2010), Instinct of God. New York, Nicholas Brealey Publishing

Bering J.M. (2006), The cognitive psychology of belief in the supernatural. American Scientist, 94, 142-149

Boehm R. (2004), Images of Women In Spirituals Traditions: Role Models for Global Understanding. Canada, Intercultural Action Committee for the Advancement of Women

Chybicka A., Kosakowska-Berezecka N. i Petrus P. (2010), Wielokulturowość w organizacji - wyzwania dla zarzadzania, [w:] A.M. Zawadzka (red.), Psychologia zarzadzania w organizacjach. Warszawa, PWN

Darewicz K. (2011), Mosuo, królestwo kobiet, „National Geographic”, 3 (138), s. 66-73

Deaux K. i Lewis L.L. (1983), Components of Gender Stereotypes, „Psychological Documents", 13, 25-83

Deaux K. i Lewis L.L. (1984), Components of Gender Stereotypes: Interrelationships Among Components and Gender Label, "Journal of Personality and Social Psychology", 46, 991-1004

Gazeta Wyborcza (2011), Królewski ślub w Bhutanie. Wydanie internetowe 13.10.

Greenberg J., Pyszczynski T. i Solomon S. (1986), The causes and consequences of a need for self-esteem: A terror management theory, [w:] R.F. Baumeister (ed.), Public self and private self (pp. 189-212). New York, Springer-Verlag

Griffith J.L. i Griffith M.E. (2008), Odkrywanie duchowości w psychoterapii. Kraków, WAM

Grzymała-Moszczyńska H. (2004), Religia a kultura. Wybrane zagadnienia z kulturowej psychologii religii. Kraków, Wydawnictwo Uniwersytetu Jagiellońskiego

Guthrie S. (2001), Why Gods? A cognitive theory, [w:] J. Andresen (red.), Religion in mind. Cognitive Perspectives on Religious Belief, Ritual and Experience. New York, Cambridge University Press 
Heszen-Niejodek I. (2003), Wymiar duchowy człowieka a zdrowie, [w:] Z. Juczyński i N. Ogińska-Bulik (red.), Zasoby osobiste i społeczne sprzyjajace zdrowiu jednostki. Łódź, Wydawnictwo UŁ

Hofstede G. (2000), Kultury i organizacje, Warszawa, Polskie Wydawnictwo Ekonomiczne

Hofstede G., i Hofstede G.J. (2007), Kultury i organizacje. Warszawa, Polskie Wydawnictwo Ekonomiczne

Hood R.W. Jr., Hill P.C. i Spilka B. (2009), Psychology of Religion. New York, Guilford Press

Kalmus M. (2009), Tybet. Legenda i rzeczywistość, Kraków, Bezdroża

Kim R. (2011), Szczęście narodowe brutto. „Wprost”, 23 (1478), dodatek

Koenig H.G. (1994), Religion and hope, [w:] J.S. Levin (red.), Religion in Aging and Health: Theoretical Foundations and Methodological Frontiers, Thousand Oaks, California, Sage Publications, Inc., 18-51

Kosakowska N. (2004), Stereotypy kobiecych I męskich ról społecznych w ocenie dzieci, nastolatków i dorostych, [w:] Z. Łoś (red.), Psychologia Rozwojowa. Emocje i doświadczenia w rozwoju - filozoficzne i metodologiczne inspiracje, Kraków, UJ

Krok D. (2008), The role of spirituality in coping: Examining the relationships between spiritual dimensions and coping styles. „Mental Health, Religion \& Culture”, 11:7, 643-653

Money.pl (2009), Wydanie internetowe, serwis z dnia 13.07

Moskowitz G.B. (2005), Social cognition: Understanding self and others. New York, The Guilford Press

Néel A.D. (2011/1929), Mistycy i magowie Tybetu. Poznań, Zysk i S-ka

Pommaret F. (2008), Bhutan. Podniebne Królestwo. Kraków, Wydawnictwo m.

Ross Z., Le Bas T. i Bell B. (2009), Nepal. Warszawa, Langenscheidt

Saucier G. i Skrzypińska K. (2006), Spiritual But Not Religious? Evidence for Two Independent Dispositions. "Journal of Personality”, 74, 5, 1257-1292

Shweder R.A., Much N., Park L. i Mahapatra M.M. (1997), The 'Big Three' of Morality (Autonomy, Community, Divinity) and the 'Big Three' Explanations of Suffering, [w:] A. Brandt i P. Rozin (red.). Morality and Health, New York, Routledge

Skrzypińska K. (2002), Pogląd na świat a poczucie sensu i zadowolenie z życia. Kraków, Impuls

Skrzypińska K. (2012), Granice duchowości - perspektywa pierwsza. „Roczniki Psychologiczne", 1(15)

Wirtualna Polska (2011), Serwis z dnia 28.06 